\title{
Complexity as a means of resilience in metropolitan port areas: Application to the Aix-Marseille case study in France
}

\author{
Nicolas Mat ${ }^{\mathrm{a},{ }^{*} \text {, Juliette Cerceau }}{ }^{\mathrm{b}}$, Miguel Lopez-Ferber ${ }^{\mathrm{a}}$, Guillaume Junqua ${ }^{\mathrm{a}}$ \\ a LGEI, Ecole Nationale Supérieure des Mines d'Alès, 6, avenue de Clavières, 30319 Alès Cedex, France \\ ${ }^{\mathrm{b}}$ Laboratoire PACTE, 14 bis avenue Marie Reynoard, 38100 Grenoble, France
}

\begin{abstract}
A B S T R A C T
Conscious of their high energy consumption and dissipation, metropolitan port areas lead transition and adaption policies to achieve and contribute to a global shift toward a low-carbon future. However, we may ask if the adaptation strategies and processes contribute to the greater resilience of port cities. Defining port cities as a system, this article examines this issue through the dynamic point of view of functional complexity, by analyzing the evolution, in time, of diversity (i.e. diversification of primary energy sources) and connectivity (i.e. development of intra- and inter-connectivity among industrial, agricultural and urban subsystems). Our research is embedded in and illustrated by the case study of AixMarseille-Provence metropolitan port area (France).

We show that the complexification processes of Marseille metropolitan port area are not linear and straightforward: they entail different phases characterized by different levels of diversity and connectivity. We identify co-evolving factors such as the development of new energy technological pathways, the emergence of a metropolitan dynamic or the change of business culture toward better cooperation, to explain these complexification dynamics. We discuss these results in regard to other metropolitan port contexts, especially in Asia, in order to assess to what extend the complexification processes of Marseille can enhance the understanding of global changes in industrial societies. We finally question the ability of these complexification strategies, implemented through industrial ecology approaches that do not deeply challenge the use of fossil energy, to respond to sustainability and resilience issues.
\end{abstract}

Keywords:

Industrial ecology

Port areas

Complexity

Resilience

\section{Introduction}

Industrialized societies are experiencing the limits of the current fossil energy system (Fischer-Kowalski et al., 1997; Sieferle, 2001; Haberl et al., 2004; Schlör et al., 2014). Jacobsson and Bergek (2011) have evaluated the huge scale of energy transformation needed to decarbonize the electricity sector by 2050 . At the international scale, metropolitan port areas concentrate environmental, economic, and social challenges in terms of the shift toward a low-carbon future. Located at the confluence of maritime and terrestrial networks, serving both local and global economies, ports areas are strategic logistics nodes for major flows of raw materials and transformed goods. They are key components in all societies, especially in a society dependent on fossil fuels and low cost energy (Mat et al., 2015). Due to their high energy consumption

\footnotetext{
* Corresponding author. Tel.: +33 (0)676015432.

E-mail address: nicolas.mat.conseil@gmail.com (N. Mat).
}

and dissipation in their various processes, these strategic areas must address transition and adaptation issues to achieve and contribute to a low-carbon future. Combining the socioecological framework (Redman et al., 2004; Haberl et al., 2006; Ostrom, 2009; Krausmann and Fischer-Kowalski, 2013) and industrial ecology developments (Chertow, 2000), Mat et al. (2015) have described and compared the different innovative regional eco-industrial development policies implemented in three metropolitan port areas (Marseille in France, Ulsan in South Korea and Ningbo in China), focusing on the changing relationships between energy, land cover, time use, and governance in each case studied. This article shows the main changes and adaptation processes (regimes and transitions) from the beginning of the 20th century until today. Even if the fossil energy use is maintained in each case study, the reduction on the total amount of the primary sources of energy presupposes the growing integration and complexity of port-city socio-ecological systems and the increased interconnectedness between local port-city components (port-related companies with urban and agricultural activities). However, we may ask if these 
trends be linked to the greater resilience of port cities? We thus echo to the growing interest of the scientific community to resilience in the implementation of industrial ecology, mainly analyzed through driving and limiting factors determining the trajectories and the diffusion of eco-industrial dynamics (Tudor et al., 2007; Sark et al., 2011; Boons et al., 2011). In particular, Mannino et al. (2015) studied the evolution of the port industrial zone of Porto Marghera, in Italy, as a path-dependant trajectory influenced by numerous internal and external factors. To be noted, Chopra and Khanna (2014) propose an analytic framework to understand resilience as an emergent property of eco-industrial network and to simulate disruptive scenarios testing the balance between resilience and sustainability of industrial symbiosis.

Following our previous research, this paper examines the question of the enhancement of the overall resilience of globalized metropolitan port socio-ecological systems. While some recent research has studied the evolution of complexity in ecological systems (Anand et al., 2010), other studies focus instead on complexity and urban growth (Bristow and Kennedy, 2015). Yet, as far as we know, complexity in industrialized and metropolitan areas has not been addressed. Clements $(1916,1936)$ describes the transitions in ecosystems, from a juvenile stage to a mature and more resilient stage. This transition is characterized by a more efficient use of material and energy input flows. Industrial ecology aims to transpose these ecological transitions to industrialized systems in which the juvenile stage is mainly based on one fossil energy (oil in Marseille today) used to feed the exponential growth of industrialized systems, and in which a more mature stage gradually diversifies energy sources with renewable energy and closed loops within the system. The level of complexity is usually used in ecological studies as an indicator of the evolution of an ecosystem, achieving an optimized and steady state equilibrium based on a variety of biological species, networking and intra- and inter-specific interactions, functional redundancy, and implementation of synergies and symbioses. More recently, complexity analysis has been established as a relevant framework for analyzing the evolution of industrialized systems toward more resilience (Meerow and Newell, 2015; Wells, 2012). For instance, Chen et al. (2010) have performed structural complexity analysis, which they applied to the Lubei industrial ecosystem in China in order to better understand the nature of industrial ecosystems. Bale et al. (2015) have explained how complexity science could be relevant to better assess and understand energy systems, which they analyze as complex adaptive systems.

Following Wallner (1999), who compared the system of a biological cell to an economic unit (the enterprise), our study proposes to describe the processes of complexification and their consequences on the resilience and stability of metropolitan port systems. We define complexity as the equilibrium between diversity and interconnectedness, and argue that metropolitan port systems may be more mature and resilient if they are able to better mobilize resources internally (closed loops) and discharge less emissions. We focus on energy issues and the use of primary energy sources appears to be a decisive factor in the socio-ecological transition toward resilience. Bristow and Kennedy (2013) show that flexible energy use and storage are relevant indicators of resilience. In particular, they highlight that the accumulation of stocks is a way to characterize resilience. In ecology, the maturity level of an ecosystem implies a certain amount of stored biomass, and by analogy, the maturity of an industrialized system depends on the level of infrastructure development. Moreover, Fagnart and Germain, 2015 have demonstrated that complexity may influence the energy intensiveness of production and that the link between complexity and energy dissipation could affect the type of longterm growth made by society.
Our research is embedded in and illustrated by a specific case study: the Aix-Marseille-Provence metropolitan area (Fig. 1), located in the South of France, which in 2012 covered $3173 \mathrm{~km}^{2}$ and was home to $1,836,788$ inhabitants. For over 100 years, economic activity in this area has been structured around harbor-based industries (petrochemical industries, paper making, steel industry, electronic \& IT industries, energy industry), traditional industries such as textile and plastics, car factories, shipbuilding, and since 1960s, logistics and container shipping. The Marseille-Fos Port is France's biggest port (in terms of weight) providing more than 43,000 jobs locally and creating 4 billion euros in added value (OCDE, 2013). As a generalist port, it handles all kinds of goods: hydrocarbons and bulk liquids (oil, gas, and chemical products), general cargo (containers and other packaging), and solid bulk (minerals and cereals).

This case study is emblematic of the energy issues facing metropolitan port areas. Experiencing a growing disconnection in its port-city interface during the 20th century, this old industrialized and strategic port area is mainly dependent on fossil energy sources (coal, oil, and gas) to cover its needs (11 Mtoe per year). The Marseille-Fos Port is the 3rd largest oil port in the world (with hydrocarbon traffic that amounted to $52.74 \mathrm{M}$ tons in 2012). Since a significant portion of global maritime exchanges today concern fossil energy products, it is relevant to ask if the scarcity of fossil fuel resources will have an impact on the long-term adaptability and vulnerability of this port-city.

\section{Assessment of complexity trends in port cities: methodological framework}

\subsection{Research boundaries: Identification of four subsystems}

In this article, we consider metropolitan port areas as complex systems, in which different subsystems are embedded. Land use and cover changes have been defined as one of the relevant indicators of socioecological transitions (Redman et al., 2004; Haberl et al., 2006). For Verburg et al. (2009), land change cannot be understood without considering the layer of soil and biomass (land cover), the purposes for which humans exploit the land cover (land use), and the provision of goods and services offered by the land system (land functions). Urban, agricultural, natural, and industrial areas can be considered in terms of the functions they provide to society, based on a wide range of activities. Land use is thus closely interconnected with time use. Time use corresponds to demographic data concerning the structure of activities and employment that are crucial factors influencing land use types and intensity and the transformation of land cover (Ohl et al., 2007). We thus assume that the metropolitan port area can be divided in four main subsystems (Fig. 2): an urban - U - subsystem (characterized by temporary and permanent residential activities, including tourism), an agricultural - A - subsystem (both agriculture and aquaculture), an industrial - I - subsystem (combining inland industrial activities as well as logistics and port industries), and a final subsystem representing natural areas (including the management of natural terrestrial and marine areas). In the Aix-Marseille metropolitan port area, the industrial port area represents $3.2 \%$ of the total surface area (industry represents $10.5 \%$ of the jobs in the territory), the urban area $12.5 \%$ (for $69 \%$ of the jobs), and the agricultural area $29 \%$ (less than $1 \%$ of the jobs). The remainder corresponds to forest and wilderness areas (some of which are protected). Over time, the areas occupied by these subsystems have changed.

This aggregation of subsystems (Wallner, 1999) in metropolitan port areas leads to a concentration of many different issues (Krugman, 1995). The challenges of management and sharing 


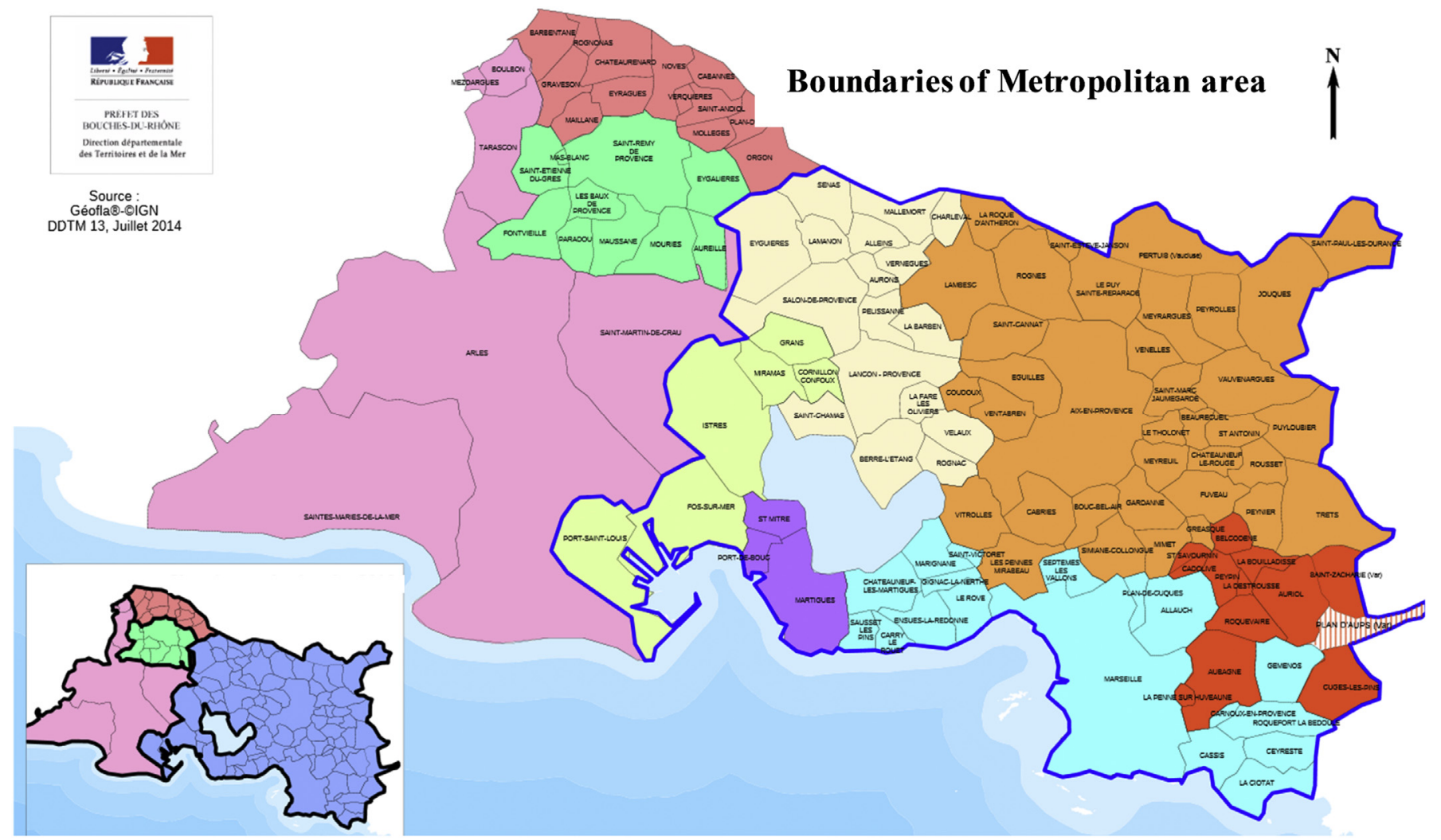

Fig. 1. Boundaries of Aix-Marseille-Provence metropolitan project area (from DDTM 13, 2014).

resources are indeed exacerbated by the coexistence of industrial, agricultural, urban, and tourism in coastal areas that are now protected. As a result, many conflicts are concentrated in metropolitan port areas concerning the management of elements such as energy, water, waste, land surfaces, and biodiversity. We must therefore seek to rationalize the use of resources (water, energy, etc.) by the different stakeholders, and manage a wide range of environmental issues including related discharges (gas emissions, liquid effluents, solid waste) in air, land, inland, and marine waters at a local scale. From the perspective of optimizing the management of resources, the multiplication of interactions among these subsystems can be considered as a lever that increases the overall complexity of the system.

Since this article aims to assess the evolution of a metropolitan port system over time based on a complexity analysis perspective, a temporal scale must also be defined. As for energy issues, three main periods have been identified that are coherent with the main timelines defined by local strategies and projects:

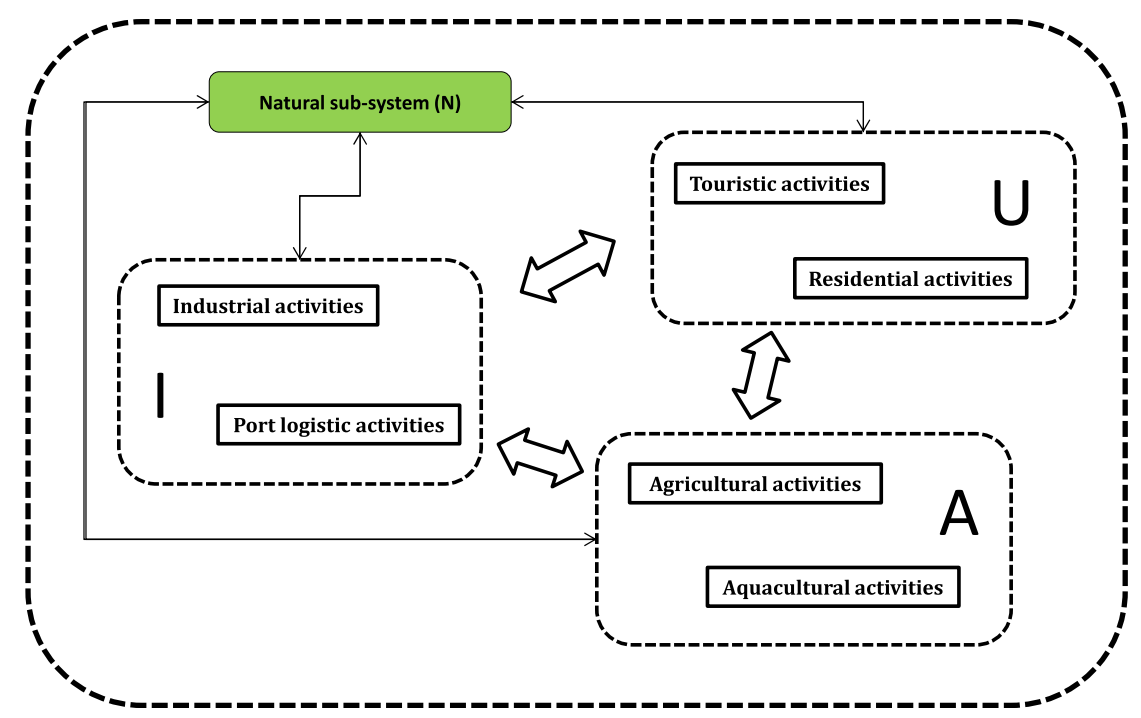

Fig. 2. Definition of subsystems included within the scope of our study. 
- T0 (2000-2012): immediate previous period,

- T1 (2012-2018): current and short-term period,

- T2 (after 2018): a mid-to long-term period,

\subsection{Theoretical and methodological framework: complexity and co- evolution}

There are theoretical grounds for concluding that the intuition stating that complexity tends to increase is generally true (Heylighen, 1999). This means that evolutionary processes lead to a general increase in complexity of the system. Complexity increases when the variety (distinction) and the dependency (connection) of part of the system increase in space and/or in time. Evolution of the system thus produces differentiation and integration. Wallner (1999) states that the complexity of a system, combining diversity and connectivity, can be increased at all levels of aggregation (local, urban, regional, national, international, and global). We here adopt the dynamic point of view of functional complexity, by analyzing the evolution, in time, of diversity and connectivity (Heylighen, 1999):

- Diversity (as parameter of differentiation process): Ashton (2009) illustrates how diversity is a strategic criterion for assessing the level of sustainability and the resilience capacity of regional industrial ecosystems. Since we focus on energy issues, we will address the level of redundancy of energy sources in an industrial system that could influence its capacity to adapt to changes in the energy mix of each subsystem and the system as a whole. We will not only consider the net imports/exports (net consumption/production) from the system, but the total flows (net activity) including the internal loops. Accordingly, a lower export figure might be proof of an increase in the internal diversification (by the diversification of interactions and a massive mobilization of internal secondary sources).
- Connectivity (as parameter of integration process): we will consider the interactions or degree of networking occurring among each subsystem and between the four subsystems (industrial, urban, agricultural, and natural subsystems). Each subsystem has its own evolution dynamics and strategies: the industrial system gradually evolves through cleaner production strategies, the urban system includes sustainable urban strategies, and the agricultural system gradually adopts sustainable and organic farming. Each subsystem thus develops inner interactions. A coevolutionary approach seeks to identify causal interactions between these evolving systems for a transition toward greater resilience (Foxon, 2011). In other words, what are the changes in each of the subsystems that influence those in the other subsystems? And what are the causal interactions between these evolving systems that enhance the overall complexity and resilience of the whole system? Foxon (2011) suggests that key events in the transition may occur through technological changes, the creation of institutions, revisions to business strategies and/or changes in user practices. We thus consider the ongoing evolution in the Aix-Marseille metropolitan port area based on Foxon's insights into coevolutionary interactions and dynamics, referring to these five key coevolving factors: technologies, institutions, business strategies, user practices, and ecosystems.

In order to assess the diversity and connectivity influencing the complexity of the system studied, we use a descriptive approach:

- Diversity indicators are based on energy data, collected and analyzed using MFA formalism (energy importation and local production), for $\mathrm{T} 0$, in order to provide insights on the diversification of energy sources from outside and the improvement of the use of material flows inside (by creating loops and mobilizing secondary raw materials - SRMs - in the system). For T1 and $\mathrm{T} 2$, a more qualitative approach is required as the significant

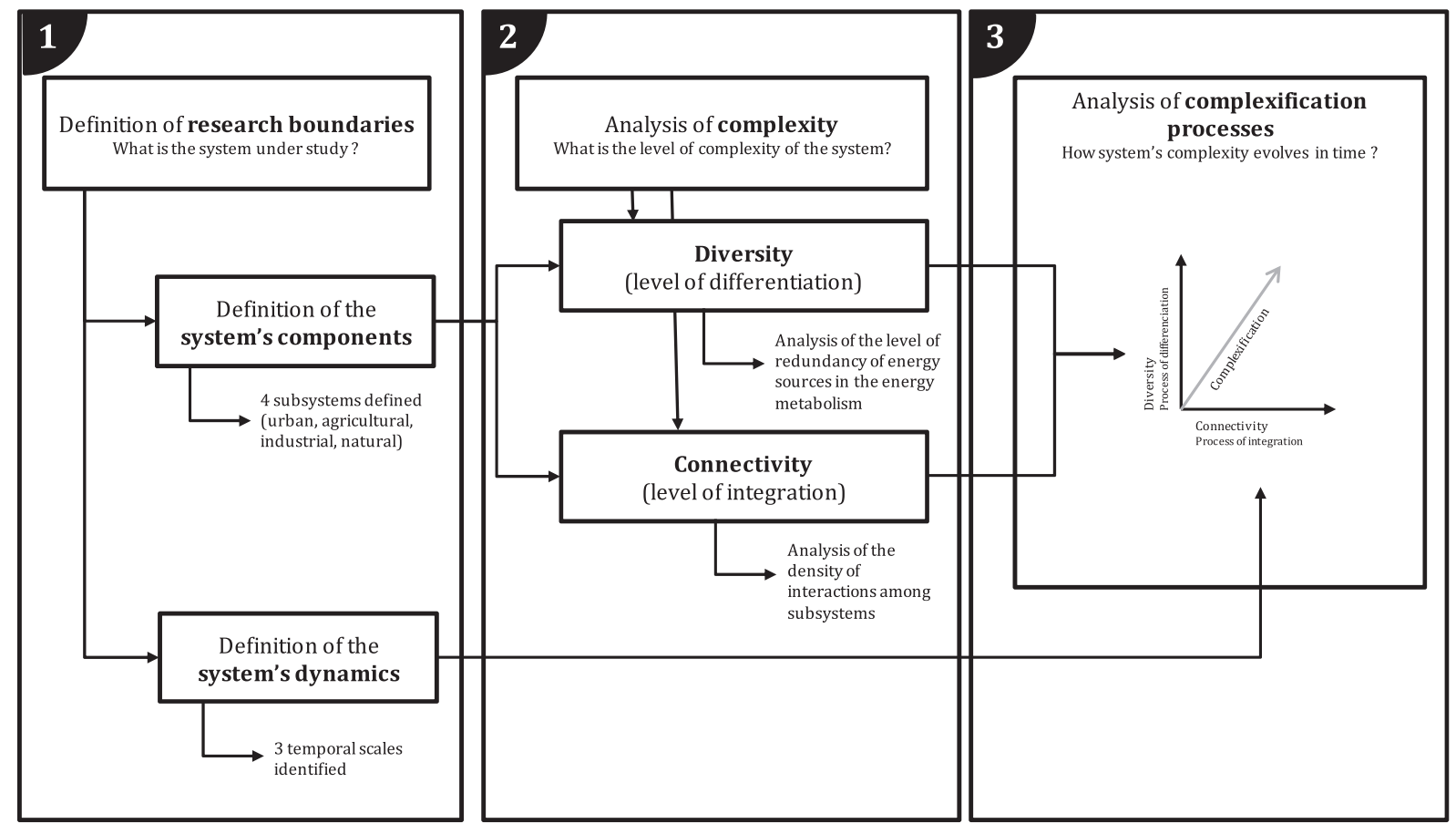

Fig. 3. Research methodological framework. 


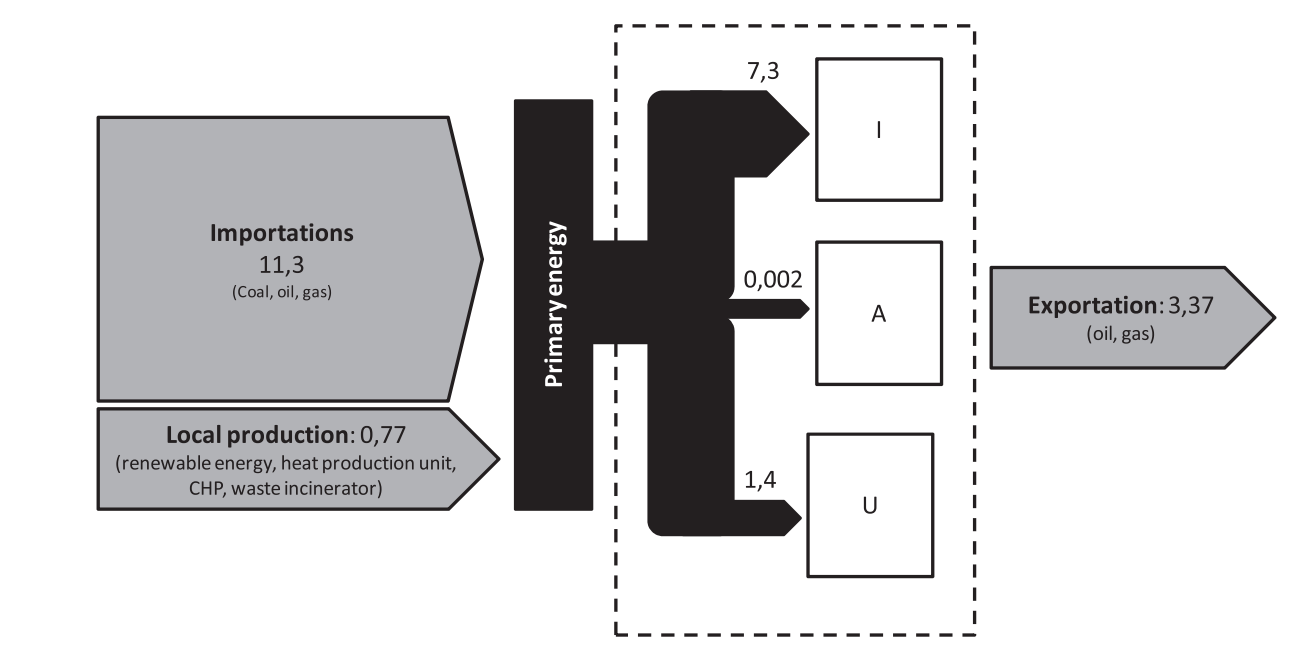

Fig. 4. Simplified energy metabolism of Aix-Marseille Provence metropolitan port area in Mtoe/year (year of reference: 2007).

evolution of the local context (evolution of strategic energy choices at local and national stages, evolution of the industrial activities under the pressure of globalized competition, national regulatory measures and scarcity of fossil resources) does not allow a consolidated MFA analysis.

- Connectivity indicators are based on the description of physical interactions (exchanges) occurring within and between the subsystems in our study. Connectivity is also assessed in terms of network density, ratio between the number of existing interactions and the total number of potential interactions (Scott, 2000).

This methodological approach, summed up in Fig. 3, enables the composition of the energy mix and the density of interactions in the exchanges of physical flows within the system to be assessed for each subsystem and each period, depending on the availability of data.

\section{Results}

3.1. Current local material interactions between stakeholders dealing with energy issues (TO)

\subsubsection{Energy diversity: predominance of external fossil energy sources}

The Aix-Marseille metropolitan port system is characterized by a significant level of external dependency on fossil energy sources: $47 \%$ of the overall local consumption (11.3 Mtoe/year) is based on primary fossil energy sources, coming from outside via the port facilities. Even if the Marseille port authority presents the port as a generalist port, able to handle all kinds of goods (hydrocarbons and bulk liquids, such as oil, gas and chemical products, general cargo including containers and other packaging, and solid bulk like minerals and cereals), in 2012, the Marseille port was the 3rd largest oil port in the world with 52.74 million tons of hydrocarbons, which is $60 \%$ of the total port traffic of 86 million tons. Adapting to the new context of supply and demand in the 1980s, the refinery sector started converting its operations by reducing its internal energy demand, and making a transition toward the production of gasoline and diesel fuel (Mat et al., 2015). LNG also became a new energy source managed by the port area, through the Fos Tonkin LNG terminal, created in 1972, and the new Fos Cavaou LNG Terminal, opened in 2010. Even if LNG equipment had been developed, LNG traffic did not increase dramatically (0.9 million tons in 1973, 3 million tons in 1983, and 5 million tons in 2009). Fig. 4 shows the global energy metabolism of the area. The industrial sector is the primary local user of energy (7.3 Mtoe/year), while the residential, tertiary, and transport sectors account for equivalent shares of about 1.4 Mtoe/year each. Agriculture is the sector that uses the smallest amount of energy (only 0.002 Mtoe/year). In this area, energy is used through heat (54\%), electricity (28\%), and fuel for transport (19\%) (AGAM, 2013). The local transformation of energy (0.8 Mtoe per year), which represents only $7 \%$ of local consumption, is mainly based on imported fossil energy sources, transformed by thermal units and Combined Heat and Power (CHP) units ( 0.52 Mtoe/year). The rest of the energy required comes from outside of the area (electrical network, oil derived products, coal).

Only a small amount of local resources (renewable sources and waste) are used (0.28 Mtoe/year). The Aix-Marseille Provence metropolitan port area has been experimenting with initiatives to achieve a low-carbon future, by developing a strategy aiming to increase energy efficiency, innovation and synergies at the metropolitan scale, in order to rebalance the energy input (6.55 MWh/ year/capita) and output (local production: $2.18 \mathrm{MWh} /$ year/capita). Currently, there are two main complementary actions implemented locally to improve this energy efficiency: the improvement of the local system and the mobilization of new local resources. Local energy production stands at 0.77 Mtoe/year, and two main kinds of sources are being used or reused (Fig. 5):

- Renewable energy sources (0.25 Mtoe/year), like hydraulic power, on-shore wind power (a capacity of 33 MW through 29 turbines implemented in the metropolitan area in South and North Caban during the last decade), and photovoltaic production (with 1.7 MW roof top PV capacity implemented in the port area in 2010).

- The secondary raw material flows (1.16 Mtoe/year), such as used solvents, blast furnace gas, and oil engine waste, are mainly provided and reused by local industrial processes (1 Mtoe/year), but also come from the urban area (municipal waste that is incinerated to produce electricity or methanized).

\subsubsection{Connectivity: compartmentalized interaction strategies}

Initiatives to reduce external energy inputs are very compartmentalized: the urban area is experimenting with some new vehicles to reduce fuel consumption, and the municipalities are trying to improve the insulation of buildings (Fig. 6). The industrial sector 


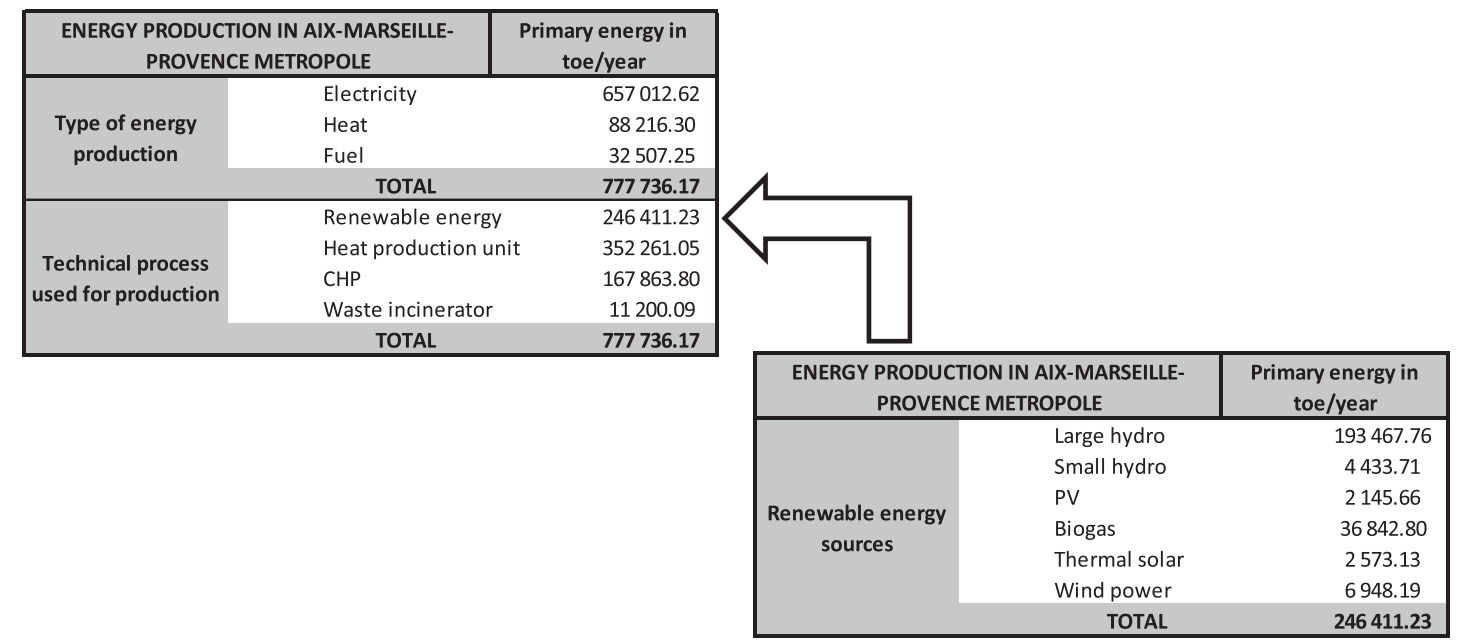

Fig. 5. Energy production in the Aix-Marseille-Provence Metropolitan area.

has dramatically improved its energy use since the 1970s, with the development of major industries in Fos, Lavéra, and Berre, the optimization of processes was integrated and flow exchanges developed between companies (Mat et al., 2015). Some industrial symbioses were also developed (I-I interactions): in 1972, the Air Liquide company started using the frigories (cold) released during the regasification of the LNG received from the Gaz de France terminal. Currently, $32 \%$ of the LNG is locally regasified through an industrial hot water loop with Air Liquide. Inter-industry synergies were also developed between Ugine Acier and Solmer, and Naphtachimie and ICI (Kinsey, 1978). The density of the eco-industrial network - calculated on the basis of the 3-3 matrix representing existing interactions between I, A and U subsystems - is thus historically high $(0,7)$ but still offers opportunities of optimization. By closing loops, these synergies make the system less dependent on external resources, thus making it more resilient. However, today these synergies represent only a small percentage of the total energy flow.

\subsubsection{Interactive causes of the evolution and co-evolution of subsystems}

For many decades, the specialization of the Marseille Port on fossil energy was a real strength, but the early 2000s could mark a turning point in Marseille's socio-ecological regime toward a new

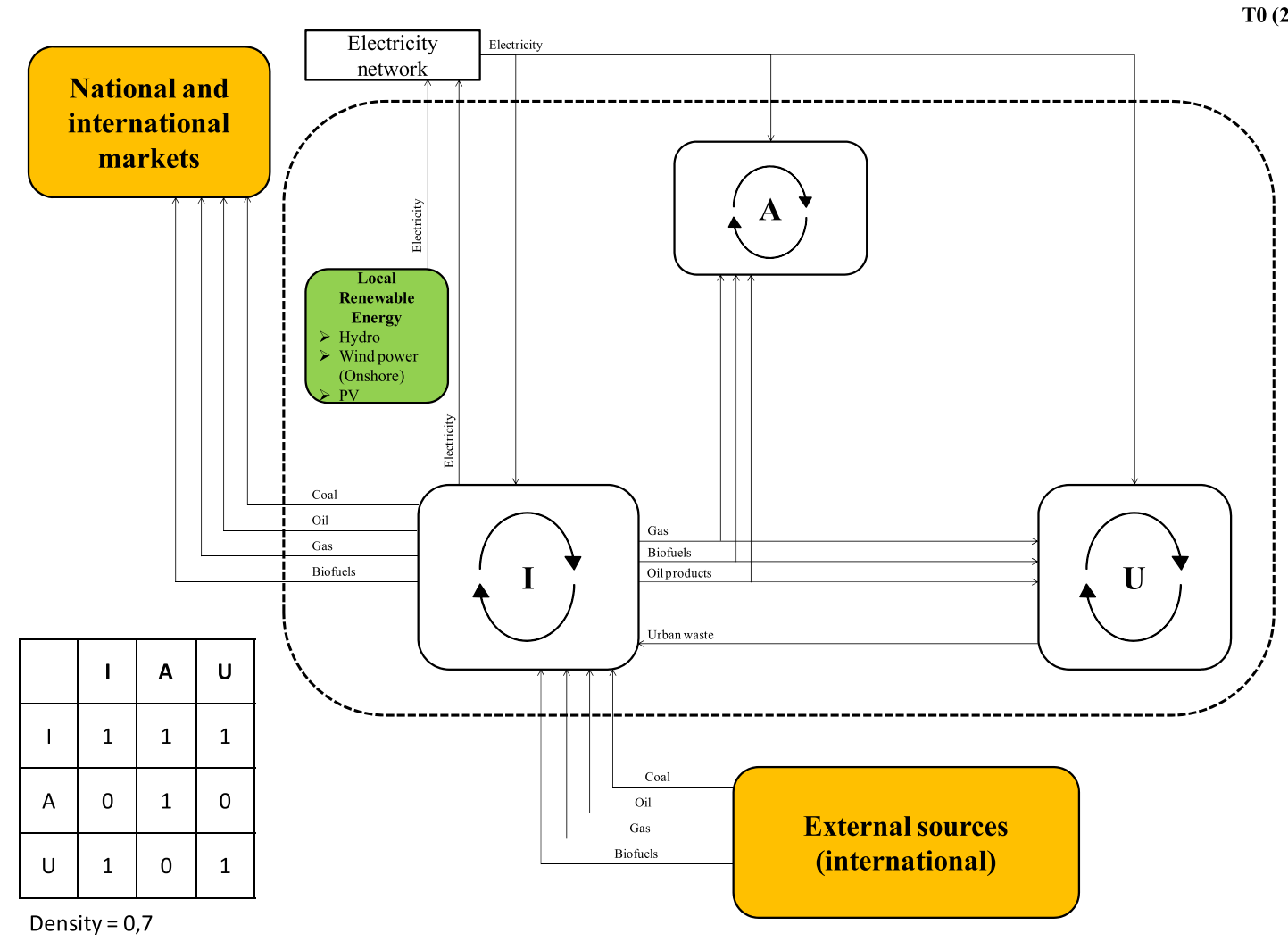

Fig. 6. Subsystem interactions until 2012 (T0). 
transition (Mat et al., 2015). The exogenous and endogenous factors in the transition that has occurred since the early 2000s can be understood using Foxon's coevolutionary framework (2011).

The first indicator refers to technologies for transforming energy. The reduction of hydrocarbon traffic by 10 million tons between 2008 and 2009 was considered to be an oil shock locally (Vinzent, 2014). This change could challenge the role of Marseille's port as an importer of fossil fuel energy, and this activity may become a weakness in a global trend in which there is pressure on fossil energy sources due to the need to mitigate climate change. In 2011, the closing of the LyondellBasell refinery was announced and different refineries were threatened to be shut down or to a significant decrease in activity. At the same time, the overall trend in the raw material market and the reorganization of the steel industry internationally may jeopardize the future of the steel industry in Fos, a major local user of energy (coal and electricity).

The second indicator concerns the institutions structuring human interactions and governance, and their impacts on the business strategies that organize activities for economic purposes. Nationally, the new port reform in 2008 redefining the role of French port authorities had an impact on port management. Focusing on issues of local planning, economic development, and multi-modal connections, ports were invited to reconnect with their local context and especially re-build the port-city interface. (Mat et al., 2015). At the same time, the project of creating an AixMarseille-Provence metropolitan area, took on a new dimension with the creation in 2012 of an inter-ministerial committee for the definition and development of the metropolitan project, to go beyond the polycentric spatial and economic organization of the area in order to rebuild territorial coherence at the metropolitan level with local stakeholders (Mat et al., 2015). A specific part of this "top-down" mission deals with the energy transition in the metropolitan area: considering that the metropolitan area only produces $7 \%$ of the energy it consumes, which only includes $2.1 \%$ in renewable energy, the objective is to move toward a local energy balance by making the most of local sources of energy (MIPPM, 2013). As industrial ecology is involved in the metropolitan strategy, fostering projects with attractive industrial synergies for new activities, and encouraging better port-city nesting through the implementation of energy exchanges between industrial and urban areas implies an evolution in the local function of the port, which will move from an importer of energy to an energy producer and operator (Mat et al., 2015).

The last indicator refers to user practices and patterns of behavior relating to human values and needs. It concerns local awareness of environmental impacts and local health issues, related to industrial emissions around the Etang de Berre and Fos area, due to the mobilization and growing opposition from local people and NGOs fighting against new industrial projects (Fos 2XL, LNG Terminal, etc.). As a consequence, all the governmental agencies launched projects concerning environmental and health studies or climate change mitigation. Environmental regulations also evolved to establish some limits in terms of $\mathrm{CO}_{2}$ emissions, reduce energy use, and introduce more renewable energies.

\subsection{New perspectives and opportunities for stakeholders dealing with energy issues (T1-T2)}

In accordance with the European guidelines for energy and climate change issues, draft legislation on the energy transition to green growth is currently being discussed in France (Assemblée Nationale, 2015). This national legislation contributes to the development of new local strategies for limiting greenhouse gas emissions and adopting a new energy mix, which will foster the emergence of new opportunities (green growth). Implementing national objectives at the regional level, the Air Climate-Energy Plan of the Provence Alpes Côte d'Azur Region (SRCAE, 2013) defines the regional guidelines and targets with respect to the 2020-2050 horizon for limiting greenhouse gases, controlling energy demand, developing renewable energy, combating air pollution, and adapting to climate change. Achieving this overall goal will require the combination of two factors: a 50\% decrease in the energy consumption in the Region between 2007 (13.8 Mtoe) and 2050 , and the development of renewable energy that will cover $2 / 3$ of the regional energy consumption by 2050 .

Since 2012, metropolitan energy issues have been defined by two areas of complexity:

- Energy diversification through the mobilization of local resources, from renewable sources (wind, solar, and geothermal) and from waste (considered as secondary raw material) produced by industry, agriculture, and urban areas. These local resources have been identified and their potential assessed by the Region, which has new powers for driving forward innovative local regulations in the field of energy savings and the development of renewable energy. The region has proposed a prospective view in order to improve its energy mix.

- Local connectivity implemented through the development of new functional interactions between subsystems, in terms of exchanges of material flows and information flows (between stakeholders). The metropolitan dynamic seems to be able to densify and promote an organized proximity between institutions and local organizations as defined by Torre (2014). For instance, one major workshop dealing with industrial ecology and the energy transition in the framework of the metropolitan project development is managed by the Director of prospective of the Marseille Port Authority. This kind of involvement of local decision-makers (from the Port authority board, the Chamber of Commerce and Industry, etc.) in the management of strategic projects is used to better mobilize local stakeholders. In terms of material exchanges, the metropolitan scale allows the current synergies between subsystems to be better highlighted (such as the exploitation of urban waste for local energy production in the Fos industrial area)

We will analyze two periods to illustrate this trend: an intermediate period (T1) from 2012 to 2018 corresponding to trial experimentations, and a medium- and long-term period (T2), after 2018, dedicated to industrial and large scale implementation of successful approaches.

\subsubsection{T1: local energy diversification experimentations and gradual connectivity between industrial and agricultural subsystems}

During this period, some projects (geothermal energy in La Feuillane, and thermal sea power production in Marseille) have been developed in the Aix-Marseille metropolitan area in order to create alternatives to traditional fossil energy sources. Other experimentations (Moine and Giraud, 2013) have been implemented like a test site for floating wind turbines (one onshore prototype in 2013 and two prototypes at sea in 2015), $\mathrm{CO}_{2}$ collection and recycling through the Vasco project and first energy research experimentation in the field of "Power-to-gas" and "Power-to-liquids". The Vasco I project has been developed to better manage the industrial emissions of $\mathrm{CO}_{2}$ in the port authority area, by exploring various alternatives such as collecting and exporting liquefied $\mathrm{CO}_{2}$ by sea for injection into oil reservoirs, or transporting it by pipeline and storing it in saline aquifers, biosequestration of $\mathrm{CO}_{2}$ with the production of algae potentially recoverable for human feed and biofuel production, and the exploitation of $\mathrm{CO}_{2}$ in a chemical unit for industrial applications. This final alternative is currently being 
tested in a semi-industrial pilot project to better assess and validate its economic potential before industrial scale development. Since 2012, through the APICE project, the port authority of Marseille has also had a single tool for measuring the air emissions produced by maritime traffic, and for modeling the evolution of emissions in some areas like the electricity used by ships that are docked, and the conversion to LNG to power ships.

Since 2014, local stakeholders have also been involved in a large industrial project, through the industrial and innovation platform of Caban-Tonkin (PIICTO), in a 1200 ha area located in the Fos industrial port. The PIICTO association brings together nine companies, the Port authority, the relevant national and regional administrations (the DIRECCTE and DREAL, the Regional Council of Provence-Alpes-Côte d'Azur, the SAN Ouest Provence authority, the French agency of Environment and Energy (ADEME)), and the Mediterranean Union of Chemical Industries (UIC). It aims to consolidate existing industrial ecosystems and to increase the region's attractiveness for new activities by developing new industrial ecology synergies between stakeholders (plug and play approach), like a steam network to exploit locally (by industry) the heat produced (nearly $150 \mathrm{t} / \mathrm{h}$ ) by the waste incinerator and other companies (Solamat Merex, etc.), and some research projects on the Innovex platform (Vasco II project, Power-to-gas by GRT Gaz, etc.). The PIICTO project is the result of two main factors: First, the evolution of the national legal framework applied to economic platforms with the introduction of technological risk prevention plans (PPRT), which allow industry to create synergies between themselves to limit risk and develop new local economic opportunities. Second, the aborted project to welcome a US factory specializing in carbon fiber has nonetheless contributed to triggering a dynamic in the region, to making stakeholders realize that an integrated platform strategy was adequate, and to enhancing the competitiveness of the industrial chemical sector at an international scale (Bayard, 2014).

In terms of connectivity among the different subsystems, some synergies are being assessed and developed between the industrial and the agricultural subsystems through the reuse of by-products (Fig. 7) from energy and non-energy plants. For instance, several kilotons per year of calcium carbonates coming from the regeneration of lime, $15 \mathrm{kt} /$ year of ash from wood boilers, $11 \mathrm{kt} /$ year of sawdust from wood cutting operations, as well as compost from green waste and sludge are reused in agricultural activities.

\subsubsection{T2: towards a new deal of interactions and energy} diversification at the metropolitan scale

The potential of new raw materials is being studied in scenarios shared and discussed by metropolitan stakeholders. Offshore wind power could become one major local renewable energy resource to produce green electricity in the Aix-Marseille metropolitan area. Other resources such as biomass (algae, wood, and agricultural waste) could be also used to provide raw local resources to the chemical industry (to produce biofuels in La Mède) and to produce electricity locally. According to this trend in the use of local resources, new interactions in conjunction with energy issues are expected (Fig. 8). Municipal and agricultural waste burned or methanized in the waste treatment plant located in the Fos area or other CHP plants could be transformed into electricity, and also generate heat to provide a steam network for the PIICTO platform, and in the long term to cover urban and agricultural needs ( $\mathrm{I}-\mathrm{U}$ and I-A interactions).

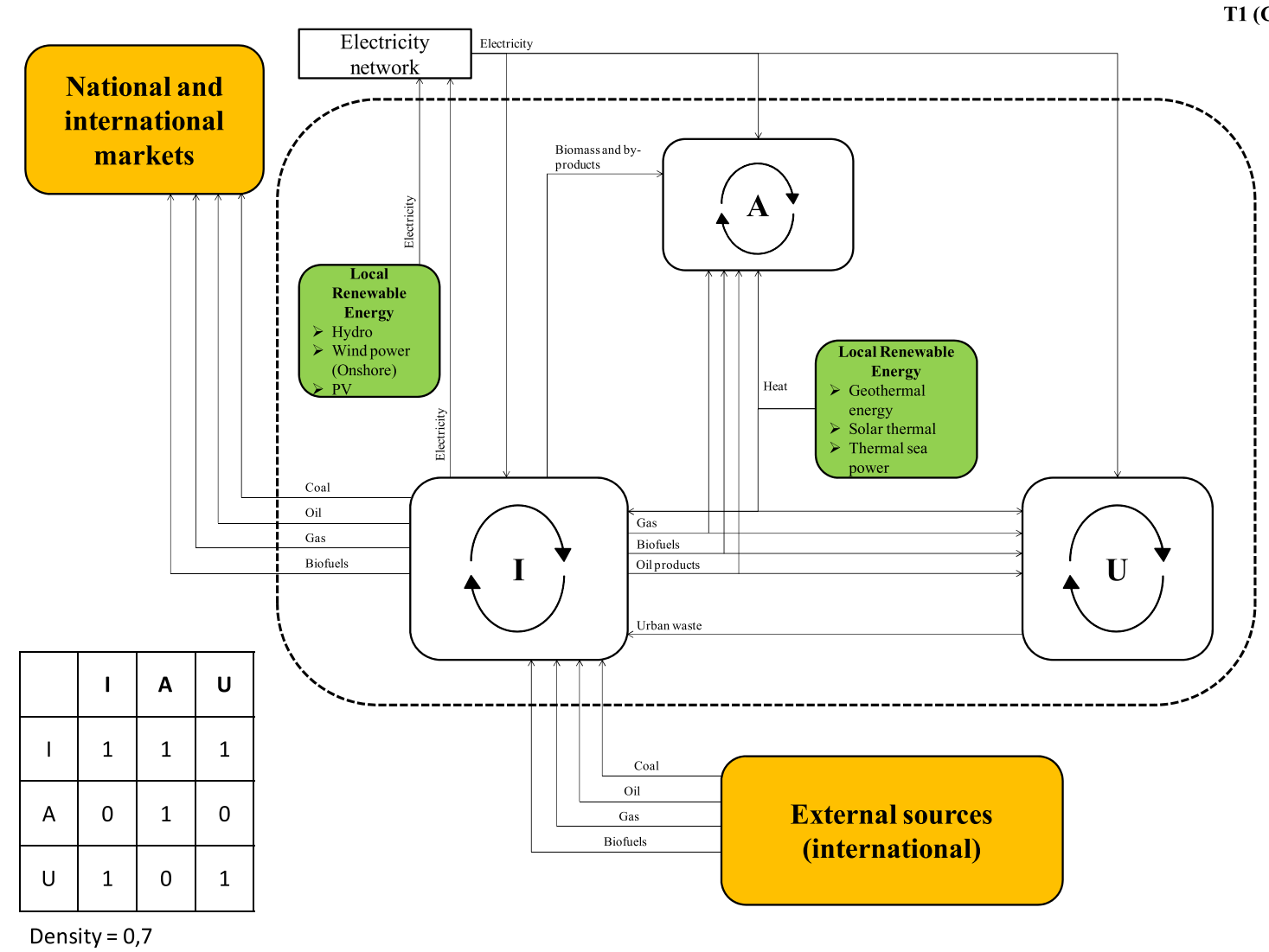

Fig. 7. Subsystem interactions from 2012 to 2018 (T1). 


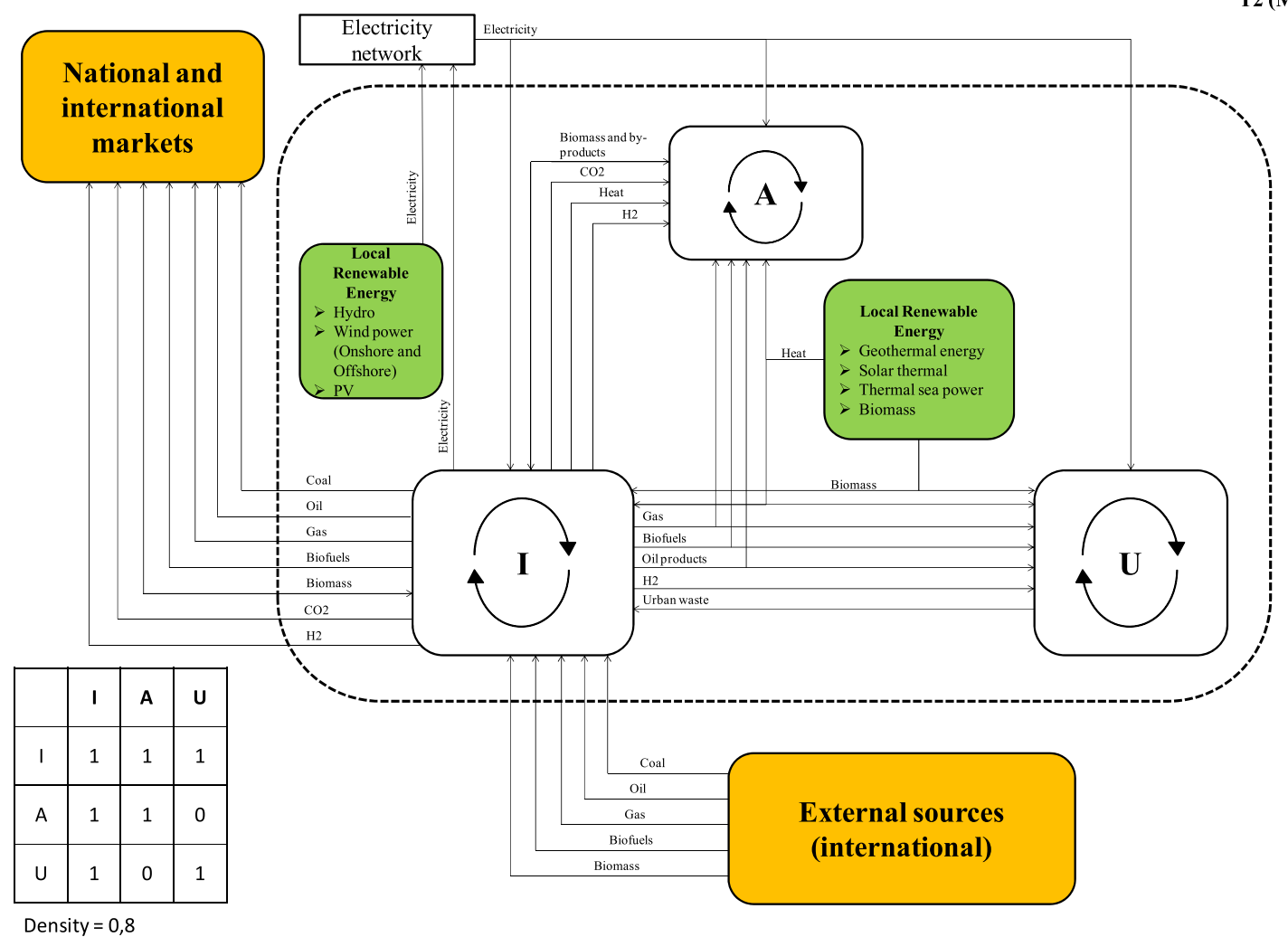

Fig. 8. Subsystem interactions expected after 2018 (T2).

The offshore wind power site in the Fos area produces electricity, and also constitutes an interesting and isolated shelter that could be used to accommodate aquaculture production (I-A interactions). Moine et Geraud (2013) have shown the expected capacity of the industrial port area to develop some new recycling loops and interactions within the industrial subsystem. These new pathways strengthen the role of the port area to achieve a more complex industrial system, which is able to both effectively exploit $\mathrm{CO}_{2}$ and to use renewable and fossil energies. This T2 scenario is very close to the "bio-industry and renewable focus" scenario designed and described by Giurco et al. (2014) in Latrobe Valley, Australia, in which the industry and manufacturing sectors provide energy to agricultural and residential users.

\subsection{Overview of complexification and coevolutionary processes}

\subsubsection{Complexification processes}

Appropriating Wallner's framework (1999), we consider complexity as a combination of energy diversification processes and the development of intra- and inter-connectivity among industrial, agricultural, urban, and natural subsystems. We provide an overview of the evolution of complexity from 2000 in the AixMarseille metropolitan port area in Table 1.

The complexification process entails different phases which are characterized by different levels of diversity and connectivity. The diversification of the energy mix by increasing the use of local resources (renewable and by-products) is the current strategy (especially seen in phase T1) being implemented to complement

Table 1

Overview of complexification processes.

\begin{tabular}{|c|c|c|c|}
\hline & T0 & $\mathrm{T} 1$ & $\mathrm{~T} 2$ \\
\hline Energy diversity & $\begin{array}{l}+/- \text { (level 1) } \\
\text { Low diversity (mainly fossil energy mix) but } \\
\text { some first R\&D projects on renewable energy } \\
\text { systems and beginning of SRM reuse (oil engine } \\
\text { waste and urban waste, blast furnace gas, etc.) }\end{array}$ & $\begin{array}{l}++ \text { (level 2) } \\
\text { Diversification of energy mix by mobilization of } \\
\text { local resources in energy systems implemented } \\
\text { at a large scale (geothermal production, solar } \\
\text { systems, on-shore and off-shore wind power, } \\
\text { etc.) } \\
\text { Second stage of R\&D projects (VASCO } 2 \\
\text { concerning algae production; solar systems; } \\
\text { off-shore wind power, etc.) }\end{array}$ & $\begin{array}{l}+ \text { (level } \mathbf{2} / \mathbf{3} \text { ) } \\
\text { Use of new technologies and development } \\
\text { of new pathways (power-to-gas, power-to- } \\
\text { liquids, etc.) }\end{array}$ \\
\hline Connectivity & $\begin{array}{l}+I-(\text { level 1) } \\
\text { Density }=\mathbf{0 , 7} \\
\text { Low connectivity with few interactions existing } \\
\text { between I, A, and U subsystems } \\
\text { Energy efficiency improvement mainly } \\
\text { implemented within each subsystem (I and A) }\end{array}$ & $\begin{array}{l}+(\text { level 1/2) } \\
\text { Density }=\mathbf{0 , 7} \\
\text { Beginning of new interactions between I, A, and } \\
\text { U subsystems (mainly biomass and by- } \\
\text { products) } \\
\text { Study of a heat network (PIICTO platform) }\end{array}$ & $\begin{array}{l}++(\text { level } \mathbf{2 / 3}) \\
\text { Density }=\mathbf{0 , 8} \\
\text { Development of interactions between I, A, } \\
\text { and } \mathrm{U} \text { subsystems }\left(\mathrm{CO}_{2} \text {, heat, } \mathrm{H}_{2} \text {, etc. }\right) \text { at the } \\
\text { metropolitan scale and beyond. }\end{array}$ \\
\hline
\end{tabular}




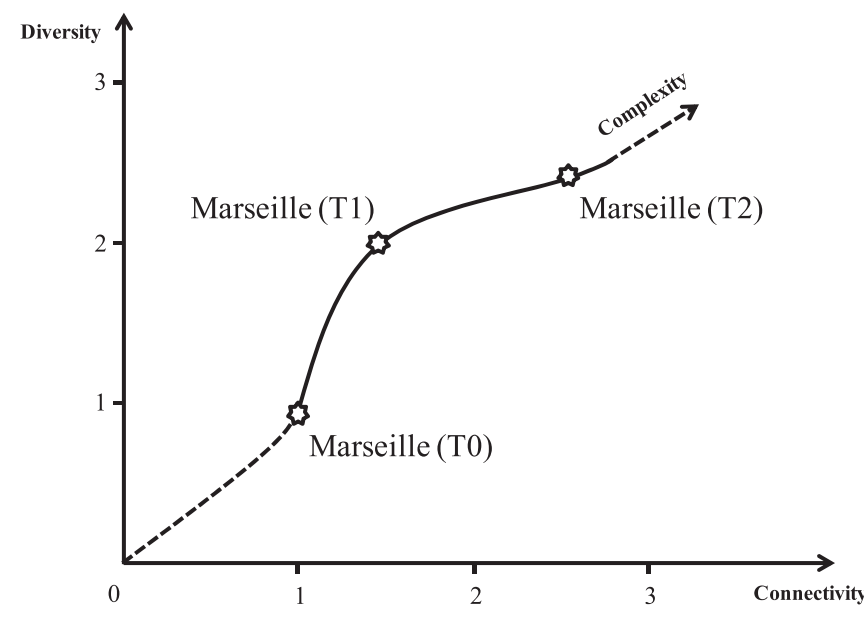

Fig. 9. Trend in complexity in the Marseille port area.

the fossil energy mix (even if the proportion of "green" energy sources remains limited in the overall energy mix used). It could be a real challenge to reuse SRM in our current industrial society where large quantities of waste are still landfilled (Duic et al., 2015). This would result in increased redundancy in the whole industrial system. A direct consequence of waste to energy transformation is that each component in a subsystem using these new sources is less vulnerable when there is tension on one of its external sources. Another current challenge is based on the implementation of power-to-gas technologies at an industrial scale, which introduces a future and growing interconnection (especially seen in phase T2) between the various energy vectors and networks. For example, wind power can be used to produce $\mathrm{H}_{2}$, which can be injected into the natural gas network, which acts as a storage unit before it is used as fuel or to produce heat and electricity. As a result, phase T0 is characterized by low diversity and connectivity (level 1). Phase $\mathrm{T} 1$ is characterized by increasing diversity (level 2), while phase T2 features higher connectivity (level 2/3) (Fig. 9).

\subsubsection{Coevolutionary processes}

We have illustrated the on-going process in the Aix-Marseille metropolitan area through Foxon's insights into coevolutionary interactions and dynamics (2011), through five key coevolving factors (technologies, institutions, business strategies, user practices, and ecosystems). We provide an overview of the evolution of these factors in Table 2.

A main driver in the evolution in the Aix-Marseille Provence metropolitan area toward a low-carbon energy future seems to be at the institutional level, through the emerging metropolitan dynamic that is prompting the development of new interactions between subsystems. Through this metropolitan strategy of developing interactions and diversifying the energy mix, the system still seems to consume resources from outside but limits its negative output. From a metabolism point of view, the system seems to be more efficient because the flows are better used and reused internally, and the local system is also beginning to produce a value-added energy flow.

\section{Discussion}

\subsection{Learning from a rapid comparison with other metropolitan port areas}

In previous research, we compared the historical evolution of the Aix-Marseille metropolitan port area with Ningbo in China and Ulsan in South Korea (Mat et al., 2015). Our results show that changes in the primary sources of energy presupposes the growing integration and functional complexity of port-city socio-ecological systems and the growing interconnectedness between local portcity components (port-related companies with urban and agricultural activities). For instance, in Ningbo, the heat network supplied by the Beilun Power plant and Ningbo steel meets industrial as well as urban and agricultural energy needs. In Ulsan, SK energy provides heat to industries today, and is planning to supply heat to neighboring urban districts. In these two cases, the goal was a more efficient use of energy by establishing links between subsystems, because the improvement was not possible within a single subsystem. The final result of subsystem interconnection could make the whole region more resilient and less vulnerable in the context of the energy transition, with a real capacity to adapt (energy mix and connectivity between local economic sectors).

We also show that the historical evolution of the metropolitan

Table 2

Overview of coevolutionary processes.

\begin{tabular}{|c|c|c|c|}
\hline & T0 & $\mathrm{T} 1$ & $\mathrm{~T} 2$ \\
\hline Technologies & $\begin{array}{l}\text { Renewable energy systems (hydraulic power, } \\
\text { on-shore wind power, and photovoltaic } \\
\text { production) }\end{array}$ & $\begin{array}{l}\text { Diversification of energy mix production by } \\
\text { mobilizing local resources (renewable energies } \\
\text { and by-products) } \\
\text { Development of energy recuperation networks } \\
\text { Development and implementation of } \\
\text { prototypes (algae production, solar systems, } \\
\text { off-shore wind power) }\end{array}$ & $\begin{array}{l}\text { Use of new technologies and development of } \\
\text { new pathways (power-to-gas, power-to- } \\
\text { liquids, etc.) }\end{array}$ \\
\hline Institutions & $\begin{array}{l}\text { Port reform } \\
\text { Metropolitan project building }\end{array}$ & $\begin{array}{l}\text { Increased legitimacy of governance at the } \\
\text { Metropolitan scale } \\
\text { Discussion workgroups integrating } \\
\text { stakeholders from all subsystems }\end{array}$ & $\begin{array}{l}\text { Metropolitan management involving } \\
\text { stakeholders from all subsystems }\end{array}$ \\
\hline Business strategies & Usual individual business models ( $\mathrm{B}$ to $\mathrm{B}$ ) & Cooperation platform (PIICTO association) & Currently unknown \\
\hline User practices & $\begin{array}{l}\text { Few interactions between I, A, and U } \\
\text { subsystems } \\
\text { SRM reuse (solvents, blast furnace gas, oil } \\
\text { engine waste, and urban waste) } \\
\text { Energy efficiency improvement within each } \\
\text { subsystem }\end{array}$ & $\begin{array}{l}\text { Beginning of interactions between I, A, and U } \\
\text { subsystems (biomass and by-products) } \\
\text { Cascades of use of energy vectors (heat, cold, } \\
\text { etc.) }\end{array}$ & $\begin{array}{l}\text { Development of interactions between } \mathrm{I}, \mathrm{A} \text {, and } \\
\mathrm{U} \text { subsystems }\left(\mathrm{CO}_{2} \text {, heat, } \mathrm{H}_{2} \text {, etc. }\right)\end{array}$ \\
\hline Ecosystems & $\begin{array}{l}\text { Conflicts over resources (land, water) between } \\
\text { subsystems }\end{array}$ & $\begin{array}{l}\text { Global carbon emissions mitigation } \\
\text { Secondary resource optimization to release } \\
\text { pressure on primary resources }\end{array}$ & $\begin{array}{l}\text { Global carbon emissions mitigation and } \\
\text { expected air quality improvement } \\
\text { Full integration of the four subsystems in the } \\
\text { development planning of the area }\end{array}$ \\
\hline
\end{tabular}


Table 3

Evolution of the role and efficiency of an incinerator plant in the local energy strategy.

\begin{tabular}{|c|c|c|c|c|}
\hline & Waste management & $\begin{array}{l}\mathrm{CO} 2 \text { emissions } \\
\text { (tons eq. } \mathrm{CO} 2 \text { ) }\end{array}$ & $\begin{array}{l}\text { Energy valorization } \\
\text { (MWh/year) }\end{array}$ & $\begin{array}{l}\text { Ratio } \mathrm{CO}_{2} / \text { energy produced } \\
\text { (tons eq. } \mathrm{CO}_{2} / \mathrm{MWh} \text { ) }\end{array}$ \\
\hline Before T0 & Landfill & 484794 & 0 & - \\
\hline T0 & $\begin{array}{l}\text { Incinerator with production/ } \\
\text { valorization of electricity }\end{array}$ & 309800 & 130257 & 2.38 \\
\hline T1-T2 (expected) & $\begin{array}{l}\text { Incinerator with production/ } \\
\text { valorization of electricity and heat }\end{array}$ & (309 800) & (966 675) & $(0.32)$ \\
\hline
\end{tabular}

port areas studied has followed a similar pathway of state and transition periods to reach their current state. The length of these periods was not similar in each case study. These evolutions are linked to the evolution of energy technologies and sources (hydraulic power, coal and oil, etc.). Our in-depth analysis of a specific case study reveals that this time discordance also affects different subsystems and stakeholders within the same metropolitan port area. The Aix-Marseille Provence metropolitan area's dynamic is indeed characterized by the co-existence of independent initiatives (wind power, $\mathrm{PV}, \mathrm{H}_{2}$ production, etc.) running at the same time as large projects (industrial scale) and small projects (micro-initiatives implemented by actors) to foster this energy transition. This particular example raises the question of the co-existence of projects, and thus the links between these initiatives in order to reach a more sustainable and stable state.

Following the findings described by Beau et al. (1978), who already considered the port of Marseille as a relevant laboratory for future changes, we can assume that the current evolution and adaptation taking place in the Marseille port area can still help us to understand global changes in industrial societies that are moving toward a post-fossil fuel energy system (Burke, 2009). In the T1 and T2 scenarios imagined for the different dynamics described in this article, Marseille should also achieve this level of efficiency in terms of resource management. We may consider the current situation in the Aix-Marseille case study as a new transition, even though there is no increase in total material and energy flows, which may appear to be a limiting factor. Accordingly, the increase in the complexity, and in the energy required to sustain it (Tainter, 2011), require a more efficient use of the resources available. However, as transitions are characterized by structural changes, it seems difficult to assert that the interactions we are observing between the subsystems, and the improvement and interpenetration between different networks (smart electrical grid, gas and petrol pipelines, heat networks, power-to-gas, etc.) will lead to real changes in the functioning of the entire system.

\subsection{Increased complexity and resilience: the evolution of $\mathrm{CO}_{2}$ emissions in $\mathrm{MWh}$}

Table 3 shows the evolution of $\mathrm{CO} 2$ direct emissions from a scenario based on landfill management (before T0), with no valorization of waste produced in a metropolitan area, to a first step in local energy management improvement through the production of electricity by an incinerator (T0), with a ratio of 2.38 tons eq. $\mathrm{CO}_{2} /$ MWh, which is an indicator of the emissions per unit of energy produced. However, in 2012, before the metropolitan development here, the incinerator plant was still considered to be disconnected from the urban area. A next phase (T1-T2) consists in reaching higher levels of efficiency ( 0.32 tons eq. $\mathrm{CO}_{2} / \mathrm{MWh}$ ) by producing and valorizing locally the electricity and the heat power produced by the incinerator plant, which becomes a real combined heat and power unit included in an energy strategy at the metropolitan scale.

Frigories (cold), currently reused and valorized in a nitrogen production plant in the Fos Tonkin area, could also be used in agro industrial processes for the transformation and conditioning of agricultural products, in order to increase the market value of these products before export. In this scenario, the $\mathrm{CO}_{2}$ produced in the port industrial area (11 $\mathrm{M}$ tons per year) would become a flow reused in agriculture (greenhouse production, as is the case in the Zeeland seaports in the Netherlands), and aquaculture (production and feeding of algae). One major characteristic of the T2 phase is that the Aix-Marseille metropolitan area would become a real producer of energy (electricity but also heat, $\mathrm{H}_{2}$, and $\mathrm{CH}_{4}$ synthesis) to complement the energy mix from fossil sources, by mobilizing local resources and developing interactions between industrial, agricultural, and urban subsystems. To achieve this scenario, the strong commitment of public and private stakeholders is needed to assume the cost of networks to drive energy and material flows (such as heat and $\mathrm{CO}_{2}$ ). It is difficult to imagine such an investment today, because the cost of fossil energy is very low. A long-term return on investment must be imagined to assess the global cost of this infrastructure. Accordingly, this goal can only be fulfilled with the strong commitment of the local, regional, and national governments.

Indeed, in the scenario described in Fig. 8, the industrial subsystem becomes a hub of flows coming from other local subsystems (urban and agricultural) and allows the transformation and production of new energy flows, through cogeneration and methanation processes. The strength of this complex approach is that the production of $\mathrm{H}_{2}$ by the electrolysis of water ultimately produces electricity using renewable energy sources during production capacity peaks. A second plant gathers this flow of $\mathrm{H}_{2}$ with the flow of $\mathrm{CO}_{2}$ in order to produce $\mathrm{CH}_{4}$ (methanation process), which can be stored in the methane network already set up at a large scale (ORECA, 2013; Boucly, 2014). This power-to-gas solution, which has been studied and monitored by national institutions (Kalinowski and Pastor, 2013), contributes to making energy production solutions based on renewable sources more flexible and in a form that is easier to use like methane. $\mathrm{H}_{2}$ can also be directly stored in the methane network system in a proportion of $6 \%$ in current networks, and at a maximum of $20 \%$ after adapting the networks. $\mathrm{H}_{2}$ and $\mathrm{CH}_{4}$ can also be produced locally using biomass methanation processes.

\subsection{Remaining issues in terms of complexity and resilience}

The improvement of the current industrial system by increasing complexity may not be sufficient in terms of sustainability (for instance with eco-industrial parks, if they only consist of synergies around waste and cascading energy, and not a complete implementation of the industrial ecology concept). Even if a variety of definitions of industrial ecology have been proposed since 1990s, we can cite White (1994), who summarized industrial ecology as "the study of the flows of materials and energy in industrial and consumer activities, of the effects of these flows on the environment, and of the influences of economic, political, regulatory, and social factors on the flow, use, and transformation of resources". He considers that we can speak about the real maturity of an anthropogenic system, and its sustainability, when the organization and 
structure of this system can function after fossil resources that cannot be perennially imported have been partially or totally excluded, by using more sustainable local and regional resources. By analogy with an ecosystem, the juvenile stage is based on a availability of energy higher than the needs, usually fossil energy, whereas the more mature stage occurs through energy diversification (renewable energy, fossil energy) and the reuse of byproducts within the system). The question of maturity can thus be addressed as follows: what increase in the energy recycling/ energy input ratio can be achieved? But maturity is not equivalent to sustainability by definition. They converge only if the supplies are not limited in time. A very mature system like a rain forest is sustainable as long as the rain levels are stable. If the rain stops due to climate change, the mature rain forest is no longer sustainable. Wallner (1999) warned that if the industrial system builds and maintains its structure and level of complexity by relying only on increasing use of fossil energy sources, then it is rather a simulated complexity, in spite of a wide variety of companies and networking or strong interactions between them. The key question is not about the fact that complexity is being built using fossil energy, but that this fossil energy is not a reliable supply. If our entire system is based on an energy supply that is not perennial, then the entire system is not perennial.

Meanwhile, Tainter (2011) argues that societies involved in an increasing complexity to solve problems become more costly. He highlights the fact that every society tries to perpetuate itself, which is the same idea for most organizations: survival is the ultimate goal independently of the original goal. When facing a threat, society increases its complexity by developing specialized functions, and by doing this, it uses more energy. Accordingly, the maximum level of complexity that can be reached depends on the amount of energy that can be mobilized. Likewise, there is a point at which the original goal of sustainability for the organization is not "sustainable" for the members of the organization, and the system collapses. In biological terms, we can observe relatively similar patterns; the progression from young to mature ecosystems increases complexity, but reduces growth for a given amount of energy. The resources are thus dissipated in regulation patterns. "Conservation policies" will not solve the problems of major impacts, or resource scarcity. We are facing a paradox that has never before been addressed: How can we reduce our energy consumption, which has been the driving force behind our development, without reducing our standard of living? If we accept the terms of this paradox, the solution will be "structural simplification" (like what is going on in the French administration), or structural disruption (such as the disappearance of central coordinated services). Small organizations can be more energy efficient, so we move from big corporations to holdings. Currently, we are arriving at a point at which we do not have abundant and inexpensive energy (or we think we will not have it in the near future, so we need to regulate energy pathways). Following Tainter (2011), we consider that increasing complexity requires more energy (or a different use of energy if the flow is limited) and if there is a supply (energy, materials ...) it will support growth and will be used immoderately (the drama of the commons).

\section{Conclusion and perspectives for the social sciences}

This article analyses the current trend in the Marseille port area toward a low-carbon future. We have described the main drivers and barriers that have influenced the dynamics of industrial ecology involving a growing number of stakeholders in the metropolitan area. Of course, low-carbon future pathways are based on innovation and new technologies to produce better and consume less. However, the different stages of evolution described in this article seem to deal with issues beyond only a technological response, which include new modes of cooperation and governance between stakeholders in the port area.

Various interactions between our different subsystems (industrial, urban, and agricultural) are already being implemented, ongoing, or expected in the Marseille metropolitan area. In this context, we have used the framework of complexity in order to describe the local dynamic based on two main issues (diversity and connectivity). In spite of the current crisis, the port area of Marseille could become a better adapted and less vulnerable industrial system by developing new forms of self-organized local synergies and by better mobilizing local energy resources (renewable energy sources and by-products). If the implementation of synergies constitutes a concrete process fostering the improvement of resource management, it might be relevant to develop a complementary approach based more on an analysis of informational flows between stakeholders, which could reveal new opportunities for industrial ecology in port and harbor areas.

A future challenge could be to include the immaterial interactions between the three main subsystems considered in our study (I, A, and U) from a social point of view, by developing a dual/ hybrid approach, following Duic et al. (2015) and Rochas et al. (2015) to complete the assessment of complexity introduced here only through material interactions. In order to assess the two main parameters (diversity and connectivity) influencing the complexity of the system studied, it could be interesting to combine a quantitative approach (exchanges of physical flows) and a qualitative approach (informational flows) through a social-material network analysis (Schiller et al., 2014) especially to study the connectivity (Frontier et al., 2004) within the system. Indeed, in the evolution of an industrial system towards sustainability (understood as maturity from an ecological point of view), we argue that the system needs to evolve from one with a material flow metabolism to one with both a material and an immaterial flow metabolism, characterized by the use of energy to maintain its structure and to dramatically increase the exchange of information between subsystems. In industrial ecosystems, interface structures (associations, etc.) thus appear necessary to densify this flow of information exchanged within the local stakeholder network. This approach could involve the academic framework of proximity, and more specifically the organized proximity described by Donsimoni (2015), and based on the critical analysis of different forms of proximity (Gilly and Lung, 2005; Rallet and Torre, 2007; Pecqueur and Zimmermann, 2004), which can be used to better understand the overall dynamics of industrial symbiosis.

\section{References}

AGAM, 2013. Aix-Marseille-Provence : la Métropole en chiffres. Rapport réalisé par l'Agence d'urbanisme de l'agglomération marseillaise pour le compte de la Mission interministérielle en charge du projet métropolitain d'Aix Marseille Provence.

Anand, M., Gonzalez, A., Guichard, F., Kolasa, J., Parrott, L., 2010. Ecological systems as complex systems: challenges for an emerging science. Divers. $n^{\circ} 2$ 395-410.

Ashton, W.S., 2009. The structure, function and evolution of a regional industrial ecosystem. J. industrial Ecol. 13 (2), 228-246.

Assemblée Nationale, 2015. Texte de la commission spéciale pour l'examen du projet de loi relatif à la transition énergétique pour la croissance verte. Annexe au rapport. Procédure accélérée. In: Nouvelle lecture du 16 avril 2015.

Bale, C.S.E., Varga, L., Foxon, T.J., 2015. Energy and complexity: new ways forward. Appl. Energy 138, 150-159.

Bayard, M., 2014. Article disponible sur le lien suivant, p. 54464. http://www industrie.com/chimie/piicto-travaille-sur-la-metamorphose-de-fos.

Beau, J.-P., Ferrier, J.-P., Girard, N., Richez, J., 1978. Fos-sur-Mer : un espace clé pour la compréhension des changements de la société française. In: Méditerranée, Deuxième série, Tome 34, 4-1978, pp. 27-44.

Boons, F., Spekking, W., Mouzakitis, Y., 2011. The dynamics of industrial symbiosis: a proposal for a conceptual framework based upon a comprehensive literature reviw. J. Clean. Prod. 19 (9-10), 905-911.

Boucly, P., 2014. L'Hydrogène, vecteur de la transition énergétique. In: Présentation 
réalisée dans le cadre d'une conférence au Sénat le 7 novembre 2014.

Bristow, D., Kennedy, C., 2013. Urban metabolism and the energy stored in cities. J. Industrial Ecol. 17 (5), 656-667.

Bristow, D., Kennedy, C., 2015. Why do cities grow? Insights from nonequilibrium thermodynamics at the urban and global scales. J. Industrial Ecol. 19 (2), 211-221.

Burke, E., 2009. The big story. Human history, energy regimes and the environment. In: Burke, E., Pomeranz, K. (Eds.), Environment and World History. University of California Press, Berkeley, Los Angeles, London, pp. 33-53.

Chen, L., Wang, R., Yang, J., Shi, Y., 2010. Structural complexity analysis for industrial ecosystems: a case study on LuBei industrial ecosystem in China. Ecol. Complex. 7, 179-187.

Chertow, M.R., 2000. Industrial symbiosis. Literature and taxonomy. Annu. Rev. Energy Environ. 25, 313-337.

Chopra, S., Khanna, V., 2014. Understanding resilience in industrial symbiosis networks: insights from network analysis. J. Env. Manag. 141, 86-94.

Clements, F.E., 1916. Plant Succession, Carnegie Institute, vol. 242. Washington Publication, Washington, DC Connell.

Clements, F.E., 1936. Nature and structure of the climax. J. Ecol. 24, 252-284.

Donsimoni, M., 2015. In: Mat, N., Cerceau, J., Alix, Y. (Eds.), Symbioses Port-Ville pour un meilleur ancrage local des activités industrialo-portuaires : l'exemple de Safi au Maroc, 2015 (coord.). Economie circulaire et Ecosystèmes portuaires. Tome IV de la Collection Les Océanides.

Duic, N., Urbaniec, K., Huisingh, D., 2015. Components and structures of the pillars of sustainability. J. Clean. Prod. 88, 1-12.

Fagnart, J.-F., Germain, M., 2015. Energy, complexity and sustainable long-term growth. Math Soc. Sci, 75, 87-93.

Fischer-Kowalski, M., Haberl, H., Hüttler, W., Payer, H., Schandl, H., Winiwarter, V., Zangerl-Weisz, H., 1997. Gesellschaftlicher Stoffwechsel und Kolonisierung von Natur. Ein Versuch in Sozialer Okologie. Gordon \& Breach Fakultas, Amsterdam.

Foxon, T., 2011. A coevolutionnary framework for analysing a transition to a sustainable low carbon economy. Ecol. Econ. 70, 2258-2267.

Frontier, S., Pichod-Viale, D., Leprêtre, A., Davoult, D., Luczak, C., 2004. Ecosystèmes : Structure, Fonctionnement, Evolution, 3 ème édition. Dunod, Paris.

Gilly, J.-P., Lung, Y., 2005. Proximités, secteurs et territoires. Cahiers du GRES, nª pp. 2005-2009.

Giurco, D., Prior, J., Boydell, S., 2014. Industrial ecology and carbon property rights. J. Clean. Prod. 80, 211-223.

Haberl, H., Fisher-Kowalski, M., Krausmann, F., Weisz, H., Winiwarter, V., 2004 Progress towards sustainability? What the conceptual framework of material and energy flow accounting (MEFA) can offer? Land Use Policy 21, 199-213.

Haberl, H., Winiwarter, V., Andersson, K., Ayres, R.U., Boone, C., Castillo, A., Cunfer, G., Fischer-Kowalski, M., Freudenburg, W.R., Furman, E., Kaufmann, R., Krausmann, F., Langthaler, E., Lotze-Campen, H., Mirtl, M., Redman, C.L., Reenberg, A., Wardell, A., Warr, B., Zechmeister, H., 2006. From LTER to LTSER conceptualizing the socioeconomic dimension of long-term socioecological research. Ecol. Soc. 11 (2), 13.

Heylighen, F. 1999. The growth of structural and functional complexity during evolution. In: Heylighen, F., Bollen, J., Riegler, A. (Eds.), The Evolution of Complexity. Kluwer Academic, Dordrecht, pp. 17-44.

Jacobsson, S., Bergek, A., 2011. Innovation system analyses and sustainability transitions: contributions and suggestions for research. Environ. Innovation Soc. Transitions 1, 41-57.

Kalinowski, L., Pastor, J.-M., 2013. Rapport au nom de l'office parlementaire d'évaluation des choix scientifiques et technologiques. L'hydrogène : vecteur de la transition énergétique ? Assemblée Nationale-Sénat.

Kinsey, J., 1978. The application of growth pole theory in the Aire Métropolitain Marseillaise. Geoforum 9, 245-267.

Krausmann, F., Fischer-Kowalski, M., 2013. Global socio-metabolic transition. In: Singh, S.J., Haberl, H., Chertow, M., Mirtl, M., Schmid, M. (Eds.), Long-term socioecological Research. Studies in society-nature Interactions across spatial and Temporal scale. Springer, New York London.

Krugman, P., 1995. Urban concentration: the role of increasing retums and transport costs. In: Proceedings of the World Bank Annual Conference on Developmen
Economics.

Mannino, I., Ninka, E., Turvani, M., Chertow, M., 2015. The decline of eco-industrial development in Porto Marghera, Italy. J. Clean. Prod. 100, 286-296.

Mat, N., Cerceau, J., Shi, L., Park, H.-S., Junqua, G., Lopez-Ferber, M., 2015. Socioecological transitions toward low-carbon port cities: trends, changes and adaptation processes in Asia and Europe. J. Clean. Prod.

Meerow, S., Newell, J.P., 2015. Resilience and complexity. A bibliometric review and prospects for industrial ecology. J. Industrial Ecol. 19, 236-251.

MIPPM, 2013. La métropole en marche: les chantiers du projet d'Aix-MarseilleProvence. Document de convergence stratégique n² 2 . Décembre 2013.

Moine, H., Giraud, J., 2013. Ecologie industrielle et transition énergétique au sein du Grand Port Maritime de Marseille. Voyage d'étude AIVP à Marseille, 17 octobre 2013.

OCDE, 2013. Vers une croissance plus inclusive de la metropole Aix Marseille: une perspective internationale. Rapport. Disponible sur sur. www.oecd.org/fr/ regional.

ORECA, 2013. Etude prospective relative à l'évolution des réseaux de distribution d'énergie. Besoins d'évolution des modèles techniques et organisationnels des réseaux de distribution d'énergie au regard des scénarios de transition énergétique en région Provence-Alpes-Côte d'Azur. Volet 1 - Hypothèses Perspect. (Version finale).

Ostrom, E., 2009. A general framework for analyzing sustainability of socioecological systems. Science 235, 419-422.

Pecqueur, B., Zimmermann, J.-B., 2004. Economie de proximités (coord.) (Hermès, Lavoisier, Paris)

Rallet, A., Torre, A. (Eds.), 2007. Quelles proximités pour Innover ?. L'Harmattan, Paris, p. 221. Collection «Géographies en liberté ».

Redman, C.L., Grove, J.M., Kuby, L.H., 2004. Integrating social science into the longterm ecological research (LTER) network: social dimensions of ecological change and ecological dimensions of social change. Ecosystems 7, 161-171.

Rochas, C., Kuzn ecova, T., Romagnoli, F., 2015. The concept of the system resilience within the infrastructure dimension: application to a latvian case. J. Clean. Prod. $88,358-368$.

Sark, D., Baas, L., El-Haggar, S., Huisingh, D., 2011. Critical success and limiting factors for eco-industrial parks; global trends and Egyptian context. J. Clean. Prod. 19 (11), 1158-1169.

Schiller, F., Penn, A.S., Basson, L., 2014. Analysing networks in industrial ecology - a review of socio-material network analysis. J. Clean. Prod. 76, 1-11.

Schlör, H., Fischer, W., Hake, J.-F., 2014. The system boundaries of sustainability. J. Clean. Prod. 88, 52-60.

Scott, J., 2000. Social Network Analysis, a Handbook, second ed. Edition Sage.

Sieferle, R.P., 2001. Subterranean Forest Energy Systems and the Industrial Revolution. White Horse Press, Cambridge.

SRCAE, 2013. Schéma Régional Climat Air Énergie Provence-Alpes-Côte d'Azur Document synthétique. Disponible en ligne depuis le 22 janvier 2014. http:// www.paca.developpement-durable.gouv.fr/IMG/pdf/Synthese_VFIN_Basse_ Def_cle0bd4d9.pdf.

Tainter, J.A., 2011. Energy, complexity, and sustainability : a historical perspective. Environ. Innovation Soc. Transitions 1, 89-95.

Torre, A., 2014. Relations de proximité et comportements d'innovation des entreprises des clusters. Le cas du cluster de l'optique en Ile-de-France, Revue Française de Gestion. Juin-Juillet 242, 49-80.

Tudor, T., Adam, E., Bates, M., 2007. Drivers and limitations for the successful development and functioning of EIPs: a literature Review. Eco. Econo 61 (2-3), 199-207.

Verburg, P.H., van de Steeg, J., Veldkamp, A., Willemen, L., 2009. From land cover change to land function dynamics: a major challenge to improve land characterization. J. Environ. Manag. 90, 1327-1335.

Vinzent, J., 2014. Un choc pétrolier affecte le port de Marseille-Fos. Marsactu.

Wallner, H.P., 1999. Towards sustainable development of industry: networking, complexity and eco-clusters. J. Clean. Prod. 7, 49-58.

Wells, J., 2012. Complexity and Sustainability. Routledge, Oxon, UK, p. 354

White, R., 1994. Preface. In: Allenby, Braden R., Richards, Deanna J. (Eds.), The Greening of Industrial Ecosystems. National Academy Press, Washington, DC. 